\section{Blood rheology and diabetic nephropathy}

Dear Sir,

Regarding the previous correspondence on their paper [1-3] Dr. Deckert and colleagues make a number of points which require clarification. Could they be asked to reply to the following questions?

1. Solerte and Ferrari [4] showed that by reducing blood viscosity in diabetic patients the level of proteinuria was lowered, and improved "... both microvascular and macrovascular afflictions." Could Dr. Deckert et al. be asked what aspects of that study were so unsatisfactory that they reject the results?

2. SDS-polyacrylamide gel electrophoresis (SDS-PAGE) has been in use for more than 20 years. In 1977 Virella and Lopes-Virella [5] wrote that the technique ". . has proved to be one of the most efficient techniques for analytical characterisation of proteinuria." Could Dr. Deckert and his colleagues provide some background to their statement concerning the ".. well known risk for artefacts," with this technique?

3. In implying that "exhaustive exercise" is necessary to cause proteinuria Dr. Deckert et al. fail to realise that virtually all urines can be shown to contain albumin by SDS-PAGE. Light exercise such as walking up two flights of stairs increases both the amount and size of the proteins in the urine. Fishberg [6] cited that work of Jehle in 1908 which showed the association of lordosis with proteinuria. There was no proteinuria while lying in bed but it became evident on assuming an upright stance. It was noted that a child who combed her hair in bed developed proteinuria but this did not happen if another person combed her hair. Such activities cannot be described as "exhaustive exercise" although they indicate how even light activities may induce proteinuria.

4. In 1934 Landis [7] reviewed his work on capillary permeability in which he demonstrated the pressure dependence of protein extravasation from capillaries. If as Dr. Deckert et al. propose ". . increased hydrostatic pressure is not the cause of albuminuria" in diabetic patients, could they be asked to comment on the pressure-related aspects of proteinuria in non-diabetic subjects?

5. If diabetic nephropathy is due to a genetically-determined defect could Dr. Deckert et al. explain why diabetic kidneys grafted into non-diabetic recipients lost the stigmata of diabetic nephropathy and functioned normally?

As it was possible to meld the results of a great deal of experimental work into a concept of diabetic neuropathy due to altered blood rheology [8] it is not easy to imagine that the pathogenesis of nephropathy is governed by greatly different conditions. Dr. Deckert and his colleagues concluded their letter with the observation that "Accumulated biological and epidemiological knowledge makes it difficult to understand the problem of diabetic complications." If the problem appears to be worsening, perhaps this is an indication that their concept is leading them in the wrong direction.

\section{References}

1. Deckert T, Feldt-Rasmussen B, Borch-Johnson K, Jensen T (1989) Albuminuria reflects widespread vascular damage. The Steno hypothesis. Diabetologia 32: 219-226

2. Simpson LO (1989) Abnormal blood rheology and diabetic nephropathy. Diabetologia 32: 766-767 (Letter)

3. Deckert T, Feldt-Rasmussen B, Borch-Johnsen K, Jensen T, Kofoed-Enevoldsen A (1989) Combined response from the authors. Diabetologia 32: 767 (Letter)

4. Solerte SB, Ferrari E (1985) Diabetic retinal vascular complications and erythrocyte filtrability: results of a 2-year follow-up study with pentoxifylline. Pharmatherapeutica $4: 341-350$

5. Virella G, Lopes-Virella MFL (1977) New approaches to the study of proteinuria. Clin Chem 23:1793-1794

6. Fishberg AM (1954) Hypertension and Nephritis. Lea \& Febiger, Philadelphia, pp 401-402

7. Landis EM (1934) Capillary pressure and capillary permeability. Physiol Revs 14: 404-481

8. Simpson LO (1988) Altered blood theology in the pathogenesis of diabetic and other neuropathies. Muscle \& Nerve 11: 725-744

Dr. L.O.Simpson

Department of General Practice

Medical School

University of Otago

Dunedin

New Zealand

\section{Response from the authors}

Dear Sir,

In discussion about previous correspondence regarding our paper [1-3] Dr. Simpson asks for certain points to be clarified.

Point 1, Dr. Simpson points to the paper of Solerte and Ferrari [4] to support his idea of the importance of blood rheology in the pathogenesis of micro- and macroangiopathy in diabetes mellitus. The study by Solerte and Ferrari is indeed a very interesting one. It comprises 70 diabetic patients of whom 23 were classified as Type 1 (insulin-dependent) diabetic patients. All the patients were given $1.2 \mathrm{~g}$ of Trental (pentoxifyllin) for two years, a drug which because of its ineffectiveness is not on the market in Denmark. This seems to be a pity because the Italian paper describes fantasticaly beneficial effects: Proteinuria declined by $>60 \%$ and in $23 \%$ of the patients retinopathy disappeared! In more than $50 \%$ ischaemic ECG changes disappeared! Intermittent claudication improved in most of the patients and creatinine clearance increased significantly. All these marvellous changes were seen without alterations in blood glucose or $\mathrm{Hb}$ $A_{1 c}$ but only by changing the filtrability of erythrocytes. However, the study was uncontrolled and not randomized and furthermore the results of both diabetic groups were mixed up. Thus, the results of the study must be regarded as interesting but inconclusive. No subsequent reports have been able to confirm the observations by Solerte and Ferrari.

Point 2, the risk of artefacts by SDS electrophoresis lies in the preparation of the protein sample before electrophoresis with di- 
thio-threitol (DTT) which by cleavage of disulphide bonds splits the proteins into their polypeptide subunits.

Point 3, it is interesting to learn that some researchers have found that children by combing their hair in bed can develop proteinuria. We have no experience with such forms of exercise but have demonstrated that long-term Type 1 diabetic patients with normal urinary albumin excretion rate during exercise with a workload of $600 \mathrm{kpm} / \mathrm{min}$ increased urinary albumin excretion rate only from $6 \pm 0.6$ to $9 \pm 1.0 \mathrm{~kg} / \mathrm{min}$, not different from non-diabetic subjects [5]. The fractional albumin clearance was also similar during exercise in these two groups.

Point 4 , the role of the intraglomerular driving forces (including hydrostatic pressure) for the filtration of water and albumin are well known but, as we pointed out to Dr. Simpson in our reply to his first letter $[2,3]$, there is no evidence from our own or other studies in diabetic subjects indicating that persistently increased microalbuminuria in Type 1 diabetic patients is caused by an increase of driving forces including blood viscosity [6].

Point 5, please see our reply to Dr. Simpson's first letter [3]. As pointed out genetic deficiency in the biosynthesis of extracellular matrix will under normoglycaemic conditions not normally lead to diabetic complications, only during hyperglycaemia. It is, therefore, by no means to be excluded that diabetic complications can reverse during long-term normoglycaemia.

We agree with Dr. Simpson that our ideas may be wrong but the extensive paper of Dr. Simpson [7] does not include arguments against our hypothesis.

Yours sincerely,

T. Deckert and B. Feldt-Rasmussen

\section{References}

1. Deckert T, Feldt-Rasmussen B, Borch-Johnson R, Jensen T, Kofoed-Enevoldsen A (1989) Albuminuria reflects widespread vascular damage. The Steno hypothesis. Diabetologia 32: 219-226

2. Simpson LO (1989) Abnormal blood rheology and diabetic nephropathy. Diabetologia 32: 766-767 (Letter)

3. Deckert T, Feldt-Rasmussen B, Borch-Johnsen K, Jensen T, Kofoed-Enevoldsen A (1989) Combined response from the authors. Diabetologia 32: 767 (Letter)

4. Solerte SB, Ferrari E (1985) Diabetic retinal vascular complications and erythrocyte filtrability: results of a 2-year follow-up study with pentoxifylline. Pharmatherapeutica $4: 341-350$

5. Feldt-Rasmussen B, Baker L, Deckert T (1985) Exercise as a provocative test in early renal disease in Type 1 (insulin-dependent) diabetes: albuminuric, systemic and renal haemodynamic responses. Diabetologia 28: 389-396

6. Feldt-Rasmussen B, Nørgaard K, Jensen $T$, Mathiesen ER, Deckert $T$. The role of hypertension in the development of nephropathy in type 1 (insulin-dependent) diabetes mellitus. Submitted to Acta Diabetologica Latina (in press)

7. Simpson L (1988) Altered blood rheology in the pathogenesis of diabetic and other neuropathies. Muscle \& Nerve 11: 725-744

Dr. T.Deckert

Steno Memorial Hospital

Niels Steensensvej 2

DK-2820 Gentofte

Denmark

\section{Book reviews}

\section{Nerup, J., et al.: Genes and Gene Products in the Development of Diabetes Mellitus: Basic and Clinical Aspects. Amsterdam: Exerpta Medica 1989.434 pp., (ISBN 0-444-81322-5), Hardcover, £ 76}

This book is the proceedings of the 3rd Nordisk Insulin Symposium on 'Genes and gene products in the development of diabetes mellitus' held in Oslo, Norway, in July, 1989. It has 25 chapters divided into five main headings covering HLA genes and gene products in insulin-dependent diabetes mellitus, regulation of cell specific gene expression, the insulin receptor gene and gene product, glucose and ion transporters and their relationship to diabetes mellitus and, lastly, approaches to the genetics of non insulin-dependent diabetes. Despite the fact that this book is in fact a compendium of individual papers presented at the meeting it follows a logical sequence and is surprisingly up to date. Particularly interesting is that after each main section, an annotated version of the discussion which took place at the symposium is presented - this helps to preserve the balance of the book and provides an interesting insight into current thoughts of where genetic research into diabetes mellitus is going in the future. The various contributions describe the 'state of the art' research into insulin-dependent and non-insulin-dependent diabetes. Whereas in insulin-dependent diabetes there is some very exciting progress, and, in particular, crossing the gap between the genetic marker and functional studies, this is not the case for non-insulin-dependent diabetes. The final section deals with approaches to the genetics of non-insulin-dependent diabetes and has a particularly valuable contribution regarding the use of linkage studies. Perhaps the only deficiency of this section is a critical analysis of the alternative population approach which seems to be favoured by many groups. I would strongly recommend this book to all those interested in genetic research into diabetes and other multifactorial diseases. It is also very useful reading for those interested in other aspects of immunological and biochemical research.

G.A. Hitman (London) von Engelhardt, D.: Diabetes. Its Medical and Cultural History. Outlines - Texts - Bibliography. Berlin, Heidelberg, New York: Springer 1989. X, 493 pp., 50Figs., (ISBN 3-540-50950-X). Hardcover, DM 156,-.

This book is a collection of 39 chapters concerning the history of diabetes all over the world, reprinted from a wide variety of times and places; none is original. The book is edited by a professor of medical history in Lübeck, most of the articles are from German sources and the presentation of the book is predominantly German, for example the importance of diabetes is related to the number of diabetics subjects in the Federal Republic. There is of course nothing wrong with that, but it limits the book's interest for readers of other nationalities and one wonders why it is published in English (only no reference to a German text appears). Most of the topics are familiar to the diabetologist but some may not be, eg a story "A Sad Fall" by Angus Wilson and "The Song of Diabetes", a long poem by Cecil Striker. The themes are varied - Paracelsus, Rollo, Paul Langerhans, Claude Bernard. The tone is ponderous; every name mentioned in the text is followed by the dates of birth and death as in a school textbook, even when it is as irrelevant to the book as Thomas Carlyle (1795-1881). Some chapter headings are scarcely enticing; for example "Epistemological fashions in interpreting disease. The deleterious effects of Western terminology on the application of the scientific tradition of Chinese medicine (illustrated by the case of diabetes mellitus vs sitis diffundens [shiao-k'o])." This is followed by a chapter of 38 pages, no less, on "The urinary flux of the ancient Indians (Prameha) (with special reference to the Carakasamhita)." Even the story of the discovery of insulin (only 8 pages) is dull by comparison with Michael Bliss's book, but that may be setting too high a standard. These may appear to be captious criticisms, but they are meant to reflect the tone and style of the book - ample, compendious, scholastic - and dull. Having ploughed through these 460 pages I still do not understand who the book is intended for.

D.A.Pyke (London) 